\title{
Abnormal regional myocardial morphology in patients with left ventricular pressure overload and preserved ejection fraction detected by multiparametric MR tissue mapping
}

Florian von Knobelsdorff-Brenkenhoff ${ }^{*}$, Anna-Katharina Mueller ${ }^{1}$, Marcel Prothmann ${ }^{1}$, Pierre Hennig ${ }^{1}$, Matthias A Dieringer ${ }^{1}$, Luisa M Schmacht ${ }^{1}$, Andreas Greiser ${ }^{2}$, Jeanette Schulz-Menger ${ }^{1}$

From 19th Annual SCMR Scientific Sessions

Los Angeles, CA, USA. 27-30 January 2016

\section{Background}

Abnormal myocardial morphology of the left ventricle (LV) may be relevant in patients with LV pressure overload for developing heart failure despite having preserved ejection fraction. We aimed to detect subclinical myocardial tissue changes in patients with aortic stenosis (AS) and hypertensive heart disease (HYP) by quantitative cardiovascular magnetic resonance.

\section{Methods}

Forty-eight patients with pressure overload (33 AS, 15 HYP and LV septum thickness $\geq 13 \mathrm{~mm}$ ) and 60 healthy
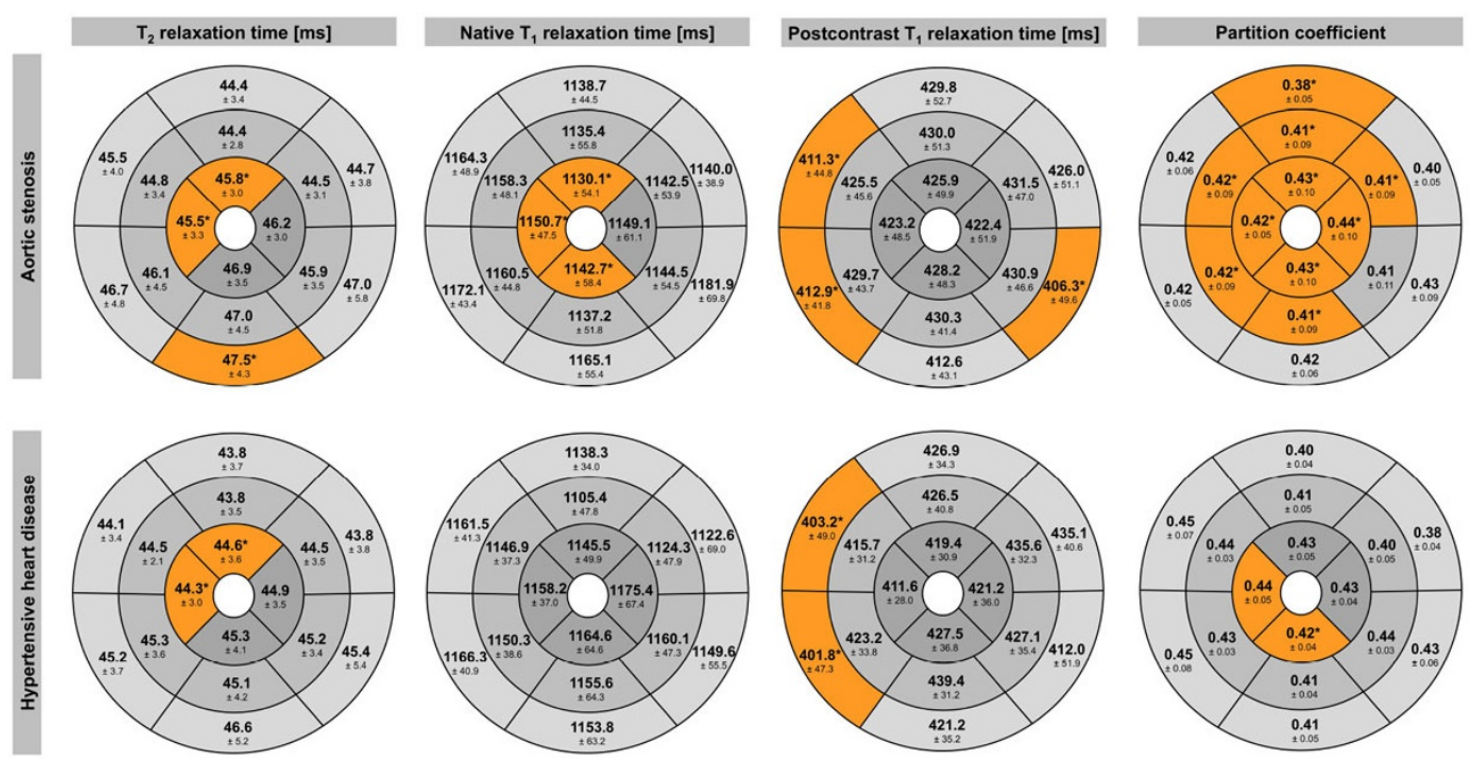

Figure 1 Mean \pm SD of $T_{2^{-}}$and $T_{1}$-relaxation times and partition coefficient per segment. Segments that differed significantly from healthy controls are marked "*" and highlighted in orange.

${ }^{1}$ Charité Medical Faculty and HELIOS clinics, Working group Cardiovascular MRI, Berlin, Germany

Full list of author information is available at the end of the article 

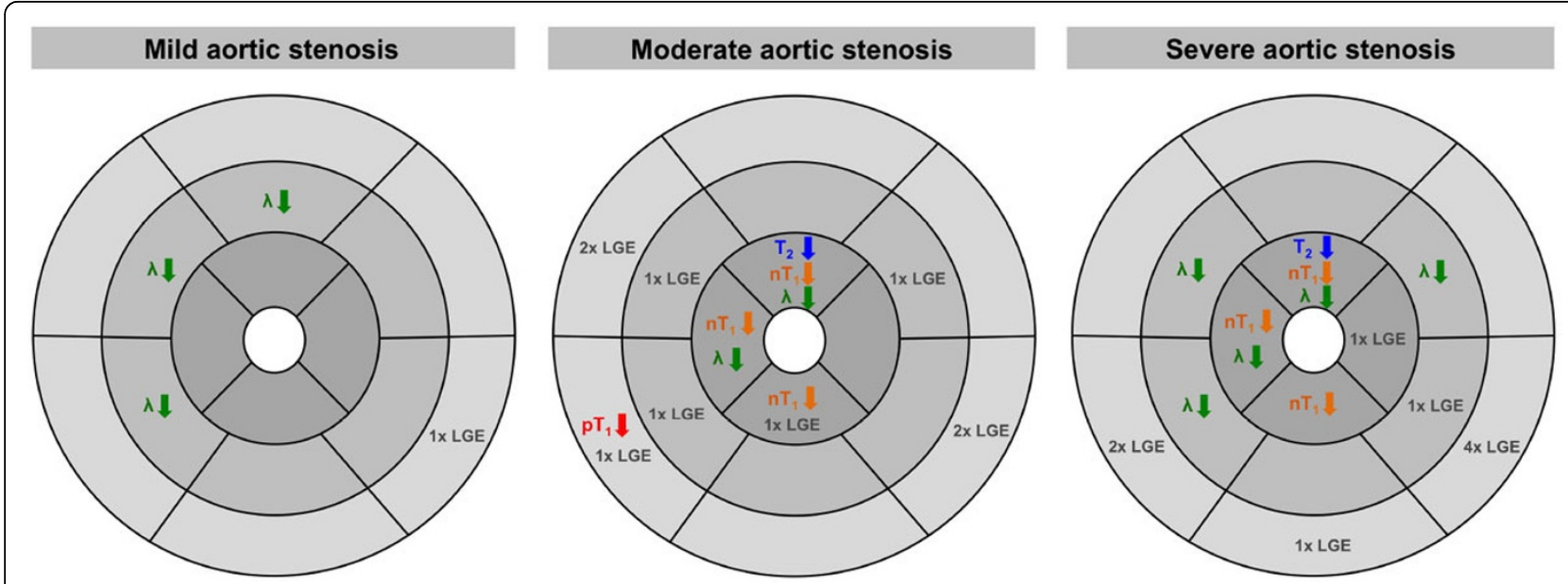

Figure 2 Synopsis of abnormal findings when comparing each AS severity grade with healthy controls.

controls were enrolled. $\mathrm{T}_{1}$-maps (modified Look-Locker inversion recovery) and $\mathrm{T}_{2}$-maps (3 steady-state freeprecession images with different preparation times) were obtained in a basal, mid-ventricular and apical shortaxis slice. $T_{1}$-maps were repeated after Gadobutrol i.v. $\mathrm{T}_{1}$ - and $\mathrm{T}_{2}$-relaxation times and the partition coefficient were determined for every segment. Focal fibrosis was assessed with late enhancement images (LGE).

\section{Results}

Figure 1 shows the $T_{2}$ - and $T_{1}$-relaxation times as well as the partition coefficient for each segment. Figure 2 provides a synopsis of the abnormal segments separated for AS severity grades. In AS, post-contrast $T_{1}$-values were reduced at the base (septum, inferolateral) indicating fibrosis, in the septum even without the presence of LGE. Apical segments differed from controls by reduced $\mathrm{T}_{2^{-}}$and native $\mathrm{T}_{1}$-values and partition coefficient, indicating abnormal regional tissue composition. With increasing AS severity, the number of segments with abnormal tissue composition increased. In HYP, postcontrast $T_{1}$-values were abnormal in the basal septum indicating fibrosis, even without the presence of LGE. Partition coefficient and $\mathrm{T}_{2}$-relaxation times were reduced in the apex compared to controls.

\section{Conclusions}

Severe AS, but also moderate AS and - to less extent HYP exhibit abnormal regional tissue composition. Multiparametric segmental mapping has potential to detect organ damage at an early stage.

\section{Authors' details}

${ }^{1}$ Charité Medical Faculty and HELIOS clinics, Working group Cardiovascular MRI, Berlin, Germany. ${ }^{2}$ Siemens Healthcare, Erlangen, Germany.
Published: 27 January 2016

doi:10.1186/1532-429X-18-S1-P336

Cite this article as: von Knobelsdorff-Brenkenhoff et al: Abnormal regional myocardial morphology in patients with left ventricular pressure overload and preserved ejection fraction detected by multiparametric MR tissue mapping. Journal of Cardiovascular Magnetic Resonance 2016 18(Suppl 1):P336.

\section{Submit your next manuscript to BioMed Central} and take full advantage of:

- Convenient online submission

- Thorough peer review

- No space constraints or color figure charges

- Immediate publication on acceptance

- Inclusion in PubMed, CAS, Scopus and Google Scholar

- Research which is freely available for redistribution 